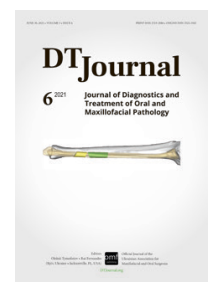

\title{
ResearchGate, a Scientific Social Network, which Is Working as Growing Database and Cannot be Ignored Neither Oral and Maxillofacial Surgeons Nor Publishers
}

Oleksii 0. Tymofieieva \& levgen I. Fesenkob,

Users' citations and publications are the site's (ie, ResearchGate) bread-and-butter. ${ }^{1}$ -Eli Kintisch

Contributing correspondent, Science magazine (2020 Impact Factor 41.845)

ResearchGate (RG) was launched in May 2008 by two physicians (Ijad Madisch and Sören Hofmayer) and computer scientist Horst Fickenscher as a social network platform for scientists, which is counting 20 million users. $^{2}$ RG is also named as networked socio-technical system for scholarly communication ${ }^{3}$, academic social network site $e^{3}$, and academic social network ${ }^{4}$. Citations, reads, RG Score, h-index, comments, personal communication via the platform and much more functions of RG are so impressive for every author. Moreover, the collection of articles`

Kyiv, Ukraine

a Chief Editor, dtjournal.org.

${ }^{\mathrm{b}}$ Managing Editor, dtjournal.org.

* Corresponding author's address: OMF Publishing LLC: Journal of Diagnostics and Treatment of Oral and Maxillofacial Pathology. 13-A Simferopolska Street, Kyiv 02096, Ukraine.

E-mail: i.i.fesenko@dtjournal.org (levgen Fesenko)

ORCID: https://orcid.org/0000-0002-8901-1632

ResearchGate: https://researchgate.net/profile/levgen-Fesenko-3 titles and abstracts/summaries with a "search" option made RG a new sophisticated database.

The principles of RG are helping to increase the dissemination of practical orientated science like the oral and maxillofacial surgery (OMS). In RG's we can find the articles from open access OMS journals like Journal of the Korean Association of Oral and Maxillofacial Surgeons, ${ }^{5,6}$ Oral and Maxillofacial Surgery Cases, ${ }^{7,8}$ etc.

RG option "Citations" is more than useful for editorial offices and publishers as it helps to track the citation in the journals included to Scopus. It facilitates monitoring of the implementation/ compliance of one of the 14 journal selection criteria for inclusion into Scopus. "Citednes of journal articles in Scopus" is important criteria from a category Journal Standing. ${ }^{9}$ 
Citation of the articles published in our journal is easy to track with the RG. For example: the article of Le et a ${ }^{10,11}$ was cited at June 16, 2021 by Weyh et $\mathrm{al}^{12,13}$ published in Atlas of the Oral and Maxillofacial Surgery Clinics.

In summary, although discussions about the operation of the ResearchGate exist, ${ }^{14}$ the benefits of this growing platform as a database should not be underestimated.

\section{REFERENCES}

1. Kintisch E. Is ResearchGate Facebook for science? Science 2021.

https://doi.org/10.1126/science.caredit.a1400214

2. ResearchGate [document on the internet]; June 21, 2021 [cited 2021 Jun 21]. Available from:

https://www.researchgate.net/about

3. Manca S. ResearchGate and Academia.edu as networked socio-technical systems for scholarly communication: a literature review. Res Learn Technol 2018; 26 .

https://doi.org/10.25304/rlt.v26.2008

4. Boudry C, Durand-Barthez M. Use of author identifier services (ORCID, ResearcherID) and academic social networks (Academia.edu, ResearchGate) by the researchers of the University of Caen Normandy (France): a case study. PLoS ONE 2020;15(9): e0238583.

https://doi.org/10.1371/journal.pone.0238583

5. Practical and diverse roles of Journal of the Korean Association of Oral and Maxillofacial Surgeons [document on the internet]; June 22, 2021 [cited 2021 Jun 22]. Available from:

ht tps:// w w w.researchgate.net/ publication/318654901_Practical_and_diverse_ roles_of_Journal_of_the_Korean_Association_of_ Oral_and_Maxillofacial_Surgeons

6. Kim SM. Practical and diverse roles of Journal of the Korean Association of Oral and Maxillofacial Surgeons. I Korean Assoc Oral Maxillofac Surg 2017;43(3):145-6.

https://doi.org/10.5125/jkaoms.2017.43.3.145
7. Autogenous tooth transplantation in a severely insufficient alveolar ridge without a bone graft: two case reports [document on the internet]; June 22, 2021 [cited 2021 Jun 22]. Available from:

ht t p s: / / w w w. researchgate.net/ publication/336734179_Autogenous_tooth transplantation_in_a_severely_insufficient_alveolar_ ridge_without_a_bone_graft_Two_case_reports

8. Waikakul A, Nisarat Ruangsawasdi. Autogenous tooth transplantation in a severely insufficient alveolar ridge without a bone graft: two case reports. Oral Maxillofac Surg Cases 2019;5(4):100129. https://doi.org/10.1016/j.omsc.2019.100129

9. Elsevier: content policy and selection [document on the internet]; June 20, 2021 [cited 2021 Jun 20]. Available from:

https://www.elsevier.com/solutions/scopus/howscopus-works/content/content-policy-and-selection

10. Le JM, Chen PH, Seidenfaden JC, Morlandt AB, Kase MT. Zygomatic implants for restoration of complex nasal defects - a case report and outcome. J Diagn Treat Oral Maxillofac Pathol 2020;4(9):152-61. https://doi.org/10.23999/j.dtomp.2020.9.2

11. Zygomatic implants for restoration of complex nasal defects - a case report and outcome [document on the internet]; June 24, 2021 [cited 2021 Jun 24]. Available from:

https:// www.researchgate.net/ publication/343870413_Zygomatic_Implants_for_ Restoration_of_Complex_Nasal_Defects_-_A_ Case_Report_and_Outcome

12. Zygomatic implants in avulsive and ablative defects [document on the internet]; June 24, 2021 [cited 2021 Jun 24]. Available from:

h t t p s:// w w w. researchgate.net/ publication/352471932_Zygomatic_Implants_in_ Avulsive_and_Ablative_Defects

13. Weyh A, Quimby A, Salman S. Zygomatic implants in avulsive and ablative defects. Atlas Oral Maxillofac Surg Clin North Am 2021;29(2):271-6. https://doi.org/10.1016/j.cxom.2021.05.001

14. Van Noorden, R. Publishers threaten to remove millions of papers from ResearchGate. Nature 2017. https://doi.org/10.1038/nature.2017.22793 